\title{
Implant Applications of Highly Corrosion-Resistant Ti-15Zr-4Nb-4Ta Alloy
}

\author{
Yoshimitsu Okazaki ${ }^{1}$ and Emiko Gotoh ${ }^{2}$ \\ ${ }^{1}$ Institute of Mechanical Systems Engineering, National Institute of Advanced Industrial Science and Technology, Tsukuba 305-8564, Japan \\ ${ }^{2}$ National Institute of Technology and Evaluation, Tsukuba 305-0044, Japan
}

The release of metal ions from the $\mathrm{Ti}-15 \mathrm{Zr}-4 \mathrm{Nb}-4 \mathrm{Ta}$ alloy in pseudo body fluids was compared with those from $\mathrm{Ti}-6 \mathrm{Al}-4 \mathrm{~V}$ and vanadium-free Ti-6Al-7Nb alloys widely used as implantable titanium alloys throughout the world, in order to choose an optimum acceleration solution for immersion testing. Bone plates, artificial hip joints of the cementless type and artificial tooth implants were experimentally fabricated using the Ti-15Zr-4Nb-4Ta alloy. The quantities of titanium ions released from the titanium alloys into phosphate-buffered saline, $\alpha$ medium and fetal bovine serum were very small, and much lower than those released into $1.2 \mathrm{mass} \% \mathrm{~L}$-cysteine, $0.05 \mathrm{mass} \% \mathrm{HCl}$ and $1 \mathrm{mass} \%$ lactic acid solutions with lower $\mathrm{pH}$ values than the phosphate-buffered saline and $\alpha$-medium. It was suggested that 1 mass $\%$ lactic acid solution was promising as an acceleration solution for immersion test. The quantities of titanium ions released from the $\mathrm{Ti}-15 \mathrm{Zr}-4 \mathrm{Nb}-4 \mathrm{Ta}$ alloy into fetal bovine serum, 1.2 mass $\%$ L-cysteine, 0.05 mass $\% \mathrm{HCl}$ and 1 mass $\%$ lactic acid solutions were approximately $30 \%$ of those of titanium ions released from the Ti-6Al-4V alloy. The total quantity of zirconium, niobium and tantalum ions released from the Ti-15Zr-4Nb-4Ta alloy was much smaller than that of elements released from the Ti-6Al-4V and Ti-6Al-7Nb alloys. Bone plates, artificial hip joints and artificial tooth implants were successfully fabricated with the $\mathrm{Ti}-15 \mathrm{Zr}-4 \mathrm{Nb}-4 \mathrm{Ta}$ alloy using conventional manufacturing processes. $\mathrm{The} \mathrm{Ti}-15 \mathrm{Zr}-4 \mathrm{Nb}-4 \mathrm{Ta}$ alloy with its excellent corrosion resistance is expected to become the preferential titanium alloy for implant applications in the future.

(Received June 3, 2002; Accepted September 2, 2002)

Keywords: titanium alloy, new implantable alloy, corrosion resistance, metal release, pseudo body fluid, experimental fabrication of implants

\section{Introduction}

The population over 65 years old is increasing every year in Japan, and the use of implants is also increasing markedly (Fig. 1). The use of artificial joints, artificial bone plates, stents, and artificial bone has been markedly increasing since 1995. In Japan, implant devices imported from the US or Europe are used more often than domestic implants. Therefore, encouraging Japan's domestic industry to manufacture new implants and conforming these implants to the configuration of Japanese bone is an important issue. Implants require both biomedical safety and mechanical compatibility. It is also essential that implant materials do not exhibit any cytotoxicity, genetic toxicity or carcinogenicity. Regarding mechanical compatibility, it is necessary that the mechanical

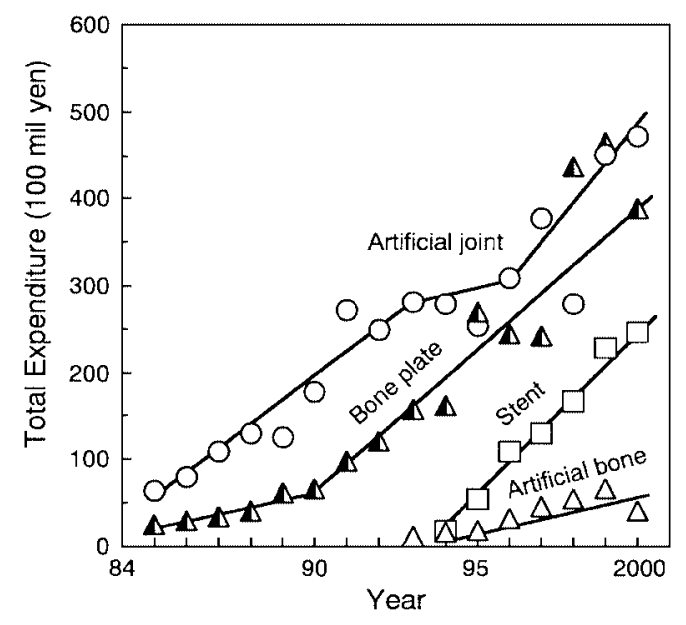

Fig. 1 Total expenditure for various implants in Japan. properties and corrosion resistance do not degrade over prolonged use.

Unalloyed titanium and Ti-6Al-4V alloy are increasingly used in implants and other medical applications because they have higher mechanical strength and more excellent corrosion resistance than stainless steels and $\mathrm{Co}-\mathrm{Cr}-\mathrm{Mo}$ alloy. The quantity of titanium alloy used in domestic implants in Japan has been increasing in the past years, and was about 4 tons in 2000.

The release of metal ions from titanium implants in humans ${ }^{1-8)}$ and animals ${ }^{9-15)}$ has been reported. The toxic effect of metal ions released from prosthetic implants has been reviewed. ${ }^{1)}$ The tissues adjacent to the prosthesis in nine hips with failed $\mathrm{Ti}-6 \mathrm{Al}-4 \mathrm{~V}$ alloy total hip replacements have been histologically examined. ${ }^{2}$ The giant-cell reaction appeared around the polyethylene debris and wear particles of the cement in the failed Ti-6Al-4V alloy total hip replacements, and it increases with increasing titanium, aluminum and vanadium concentrations in the dry tissue. The mean titanium concentration in serum for patients with a loose total hip replacement made of Ti-6Al-4V alloy $(8.1 \mathrm{ng} / \mathrm{mL})$ is slightly higher than that for patients with a normally functioning primary cementless total hip replacement $(4.1 \mathrm{ng} / \mathrm{mL}){ }^{3)}$ The slow accumulation of aluminum and vanadium ions released into the soft tissue surrounding the prosthesis has been reported. ${ }^{5)}$ On the release of metal ions from titanium materials into pseudo-body fluid, considerable research has also been conducted. ${ }^{16-21)}$ In particular, in order to reduce the harmful release of metal ions such as vanadium, the effects of various surface treatments on the dissolution of implant materials have been examined intensively.

Vanadium is considered to be an essential element in the body, but is classified in the toxic group at excess levels; ${ }^{17)}$ 


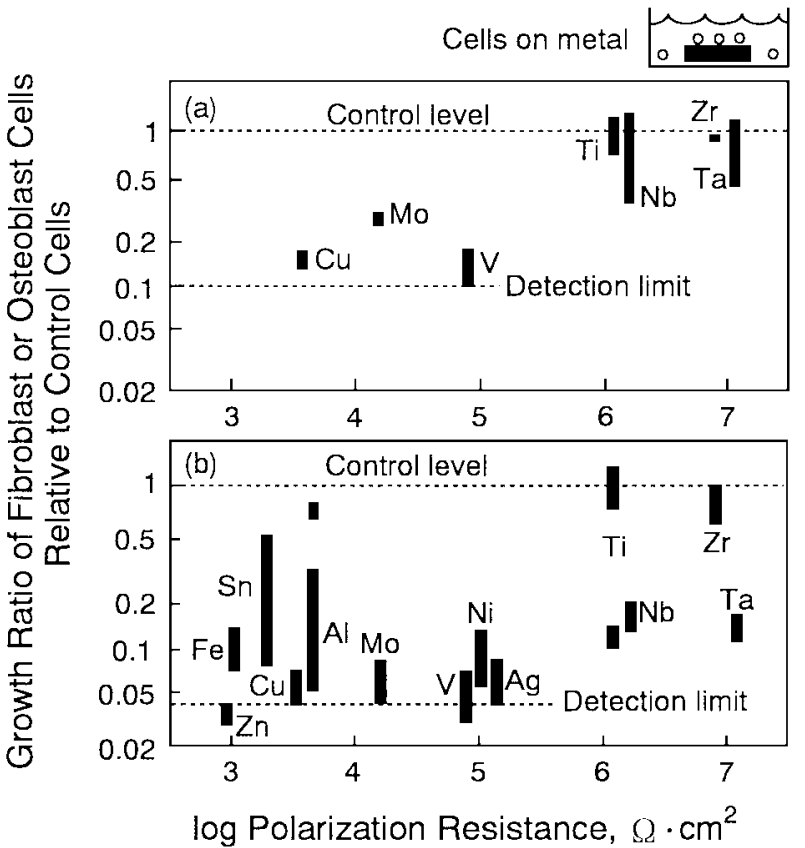

Fig. 2 Relationship between log polarization resistance and cytocompatibility with fibroblast (a) and osteoblast (b) cells.

aluminum is classified in the capsule (scar tissue) group. Titanium, zirconium, niobium and tantalum exhibit excellent biocompatibility, and are in the loose connective vascularized (vital) group as regards tissue reaction. ${ }^{22)}$ It has been reported that of the 70 metals in the periodic table, only zirconium and titanium support osteoblast growth and osteointegration, as summarized in Fig. 2. ${ }^{23)}$ As the relative growth ratio of fibroblast or osteoblast cells shown on the Y-axis decreases from 1, the cytotoxic effect of metal increases. Titanium, zirconium, niobium and tantalum on the right-hand side of the $\mathrm{X}$-axis have considerably superior corrosion resistance. The effects of various metals on cell viability have been reported using metallic particles. ${ }^{24-26)}$ The colony formation ratio of the V79 cells derived from the lung tissue of a Chinese hamster and the growth ratios of the murine fibroblast L929 and murine osteoblastic MC3T3-E1cells relative to the control cells sharply decreased when the vanadium concentration in the medium was increased to $0.2 \mathrm{mg} / \mathrm{L}$, and it became zero at approximately $0.5 \mathrm{mg} / \mathrm{L}$. Since the quantities of the metal ions released into the medium were small $(<0.3 \mathrm{mg} / \mathrm{L})$ for titanium, zirconium, tantalum and niobium particle extractions, the relative growth ratios of the L929 and MC3T3-E1 cells were equal to 1 (non-cytotoxic). ${ }^{26)}$

The vanadium-free Ti-6Al-7Nb alloy is specified in the Internal Standard Organization (ISO) 5832-11 standard as an $\alpha+\beta$ type. The near- $\beta$ type Ti-13Nb-13Zr alloy is specified in the American Society for Testing and Materials (ASTM) F 1713 standard. The $\beta$ type Ti-12Mo-6Zr-2Fe alloy, which has a slightly lower Young's modulus than the $\alpha+\beta$ type alloy, is specified in the ASTM F 1813 standard. Unalloyed tantalum for surgical applications is specified in the ISO 13782 standard.

Our research group has reported on the effects of zirconium, niobium, tantalum, tin and palladium with regard to their mechanical property and biocompatibility with cultured

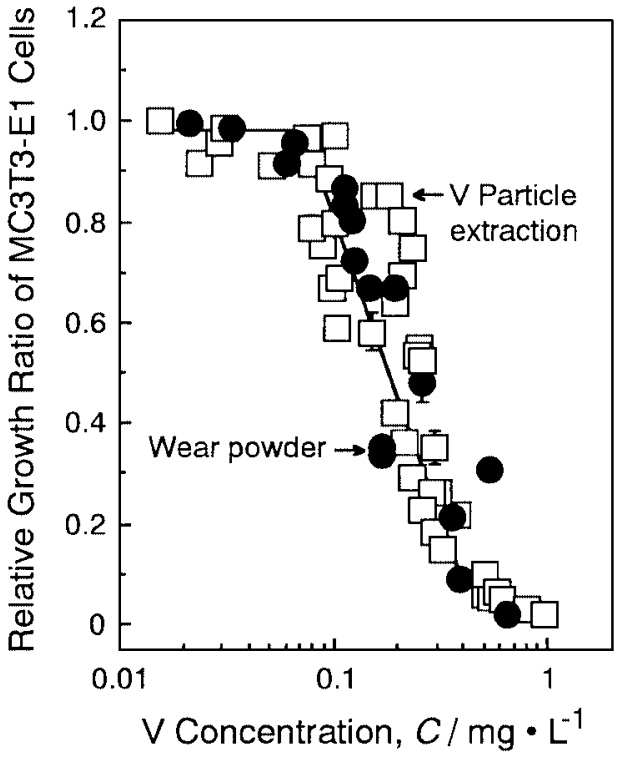

Fig. 3 Comparison between effect of $\mathrm{V}$ ions released from $\mathrm{Ti}-6 \mathrm{Al}-4 \mathrm{~V}$ alloy wear powder generated with an apatite ceramic pin and effect of $\mathrm{V}$ ions obtained in the case of medium extraction using high-purity $\mathrm{V}$ particles on the relative growth ratios of MC3T3-E1 cells.

cells, and on the corrosion resistance of alloys using anodic polarization tests in a pseudo-body fluid. ${ }^{27-38)}$ The anodic polarization property of titanium alloy was improved when zirconium, niobium, tantalum and palladium were added because the resultant $\mathrm{ZrO}_{2}, \mathrm{Nb}_{2} \mathrm{O}_{5}, \mathrm{Ta}_{2} \mathrm{O}_{5}$ and $\mathrm{PdO}$ strengthened the $\mathrm{TiO}_{2}$ passive film that formed on the titanium alloy. The titanium alloy disk was worn with an apatite ceramic pin in Eagle's medium, and the wear powder was sterilized in ethanol and added to the culture medium. ${ }^{37)}$ The growth ratios of the L929 or MC3T3-E1 cells with the Ti-6Al-4V alloy wear powder relative to the control cells decreased lower those that with the $\mathrm{Ti}-15 \mathrm{Zr}-4 \mathrm{Nb}-4 \mathrm{Ta}$ alloy wear powder. The concentration of vanadium released from the wear powder into the medium increased with increasing amounts of wear powder. This effect on the relative growth ratios of MC3T3E1 cells approximately agreed with the results estimated from medium extraction using high-purity vanadium particles, as shown in Fig. 3. For the $\mathrm{Ti}-15 \mathrm{Zr}-4 \mathrm{Nb}-4 \mathrm{Ta}$ wear powder, the maximum titanium concentration released from the wear powder roughly agreed with the results obtained using highpurity titanium particles. In contrast, for zirconium, niobium and tantalum, the maximum metal concentrations released from the wear powders were much lower than those obtained with high-purity metal particles. The effect of friction on the anodic polarization properties of the metallic biomaterials in pseudo-body fluids has been investigated. ${ }^{38)}$ The Ti-15Zr$4 \mathrm{Nb}-4 \mathrm{Ta}$ alloy exhibited excellent corrosion resistance under friction.

In this study we compare the release of metallic elements among Ti-6Al-4V, vanadium-free Ti-6Al-7Nb and $\mathrm{Ti}-15 \mathrm{Zr}-4 \mathrm{Nb}-4 \mathrm{Ta}$ alloys in pseudo-body fluids. In particular, the influence of an amino acid in 1.2 mass\% L-cysteine, 1 mass $\%$ lactic acid and 0.05 mass $\% \mathrm{HCl}$ solutions on titanium ion release was examined in order to choose an optimum acceleration solution for immersion testing. Moreover, bone plates, artificial hip joints and artificial tooth implants were 
Table 1 Chemical composition (mass\%) of materials used.

\begin{tabular}{lcccccccccccccccc}
\hline Titanium alloy & $\mathrm{Zr}$ & $\mathrm{Nb}$ & $\mathrm{Ta}$ & $\mathrm{Pd}$ & $\mathrm{Al}$ & $\mathrm{V}$ & $\mathrm{Fe}$ & $\mathrm{O}$ & $\mathrm{N}$ & $\mathrm{H}$ & $\mathrm{C}$ \\
\hline Ti-6Al-4V ELI & - & - & - & - & 6.24 & 4.19 & 0.179 & 0.174 & 0.0032 & - & 0.007 & $\mathrm{Bal}$ \\
Ti-6Al-7Nb & - & 6.55 & 0.01 & - & 5.97 & - & 0.22 & 0.18 & 0.01 & 0.001 & 0.01 & Bal. \\
Ti-15Zr-4Nb-4Ta & 14.83 & 3.97 & 4.01 & 0.16 & - & - & 0.04 & 0.22 & 0.05 & 0.0057 & 0.01 & Bal. \\
\hline
\end{tabular}

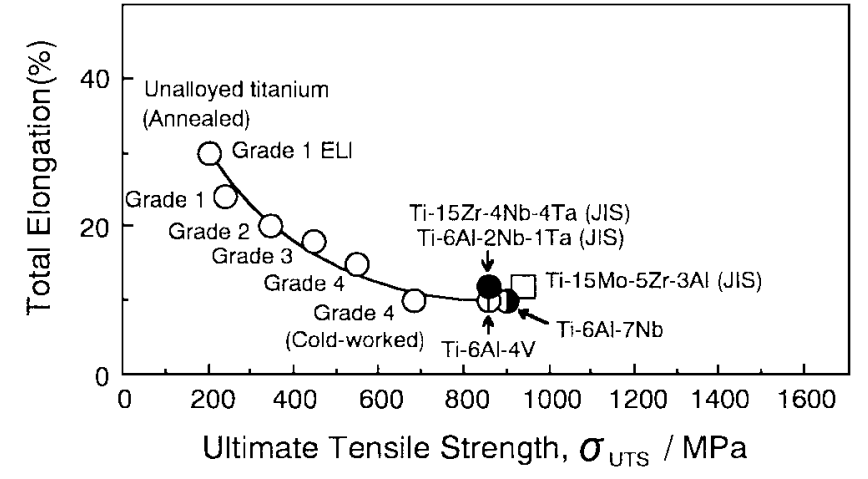

Fig. 4 Relationship between minimum values for ultimate tensile strength and total elongation specified in ISO and JIS standard.

experimentally fabricated using the $\mathrm{Ti}-15 \mathrm{Zr}-4 \mathrm{Nb}-4 \mathrm{Ta}$ alloy to examine whether this new titanium alloy could be adopted for the conventional manufacture of Ti-6Al-4V and Ti-6Al$2 \mathrm{Nb}-1 \mathrm{Ta}$ alloys.

\section{Experimental Method}

\subsection{Alloy specimens}

The titanium alloys currently specified in the Japanese Industrial Standard (JIS) T 7401, namely $\alpha+\beta$ type Ti-6Al$7 \mathrm{Nb}$, and $\mathrm{Ti}-15 \mathrm{Zr}-4 \mathrm{Nb}-4 \mathrm{Ta}$ containing $0.2 \% \mathrm{Pd}, 0.2 \% \mathrm{O}$ and $0.05 \% \mathrm{~N}$, were melted by vacuum-arc melting. After $\beta$ forging (at $1050^{\circ} \mathrm{C}$ for $4 \mathrm{~h}$ ) and $\alpha-\beta$ (starting temperature: $750^{\circ} \mathrm{C}$ ) forging, the $\mathrm{Ti}-15 \mathrm{Zr}-4 \mathrm{Nb}-4 \mathrm{Ta}$ and $\mathrm{Ti}-6 \mathrm{Al}-4 \mathrm{~V}$ alloys were annealed for $2 \mathrm{~h}$ at $700^{\circ} \mathrm{C}$ and then cooled in air. The Ti$6 \mathrm{Al}-7 \mathrm{Nb}$ alloy was annealed for $2 \mathrm{~h}$ at $740^{\circ} \mathrm{C}$. The chemical compositions of these titanium alloys are shown in Table 1. The beta transus and density of the Ti-15Zr-4Nb-4Ta alloy were $795^{\circ} \mathrm{C}$ and $4.98 \mathrm{Mg} / \mathrm{m}^{3}\left(\mathrm{~g} / \mathrm{cm}^{3}\right)$, respectively. The minimum values of ultimate tensile strength and total elongation for the titanium alloys specified in the ISO 5832 standard are summarized in Fig. 4. The minimum values of the mechanical properties of the titanium alloys originally developed for medical use in Japan and specified in the JIS 7401 standard are also compared in Fig. 4.

\subsection{Static immersion test}

The static immersion test was performed in accordance with the currently specified JIS T 0304 standard. Five plate specimens, each $20 \mathrm{~mm} \times 40 \mathrm{~mm} \times 1 \mathrm{~mm}$ thick, were cut from each of the Ti-6Al-4V, Ti-6Al-7Nb and Ti-15Zr-4Nb-4Ta alloy specimens. Static immersion tests were conducted in phosphate-buffered saline [PBS(-) containing per $1 \mathrm{~L} \mathrm{NaCl}$ : $8 \mathrm{~g}, \mathrm{KCl}: 0.2 \mathrm{~g}, \mathrm{Na}_{2} \mathrm{HPO}_{4}: 1.15 \mathrm{~g}, \mathrm{KH}_{2} \mathrm{PO}_{4}: 0.2 \mathrm{~g}, \mathrm{pH}=$ 7.2; Nissui], $\alpha$-medium ( $\alpha$-modified Eagle's medium, powder, $\mathrm{pH}=8.4$ : ICN Biomedicals Inc., U.S.A.) and fetal bovine serum $(\mathrm{pH}=7.1), 1.2$ mass \% L-cysteine $(\mathrm{pH}=2.1)$,
$1 \mathrm{mass} \%$ lactic acid $(\mathrm{pH}=2.6)$ and 0.05 mass $\% \mathrm{HCl}(\mathrm{pH}=$ 2.0) solutions at $37^{\circ} \mathrm{C}$. The 1.2 mass $\%$ L-cysteine solution was prepared from L-cysteine hydrochloride monohydrate. The 0.05 mass $\% \mathrm{HCl}$ solution was prepared from ultrahighpurity hydrochloric acid concentrate (TAMAPURE-AA-10, Tama Chemicals Co., Ltd.). The $\alpha$-medium solution contained 10 vol\% fetal bovine serum and $7.5 \% \mathrm{NaHCO}_{3}$ solution $(1 \mathrm{vol} \%){ }^{24)}$

The plate specimens were surface-finished with waterproof emery paper up to 1000 grit under running water and then ultrasonically cleaned. These specimens were placed in polypropylene bottles and separately sterilized in an autoclave for $30 \mathrm{~min}$ at $121^{\circ} \mathrm{C}$. The polypropylene bottles used for the immersion tests were carefully cleaned with 5 vol\% concentrated $\mathrm{HNO}_{3}$ solution and ultrapure water $(18.3 \mathrm{M} \Omega$ ) to remove impurities, and thereafter sterilized in an autoclave. Phosphate-buffered saline solution was also sterilized in an autoclave. The other solutions, except for the $0.05 \mathrm{mass} \% \mathrm{HCl}$ solution, were sterilized with a $0.2 \mu \mathrm{m}$ membrane filter. Then $50 \mathrm{~mL}$ of the solutions was poured into the polypropylene bottles containing the plate specimens. The bottle lids, except for those containing the $\alpha$-medium, were tightly sealed to maintain aseptic conditions. Bottles containing the $\alpha$-medium were not tightly sealed to adjust $\mathrm{pH}$. All the bottles were kept inside an incubator in a $95 \%$ air- $5 \% \mathrm{CO}_{2}$ atmosphere for $7 \mathrm{~d}$ at $37^{\circ} \mathrm{C}$.

The concentrations of titanium, aluminum, vanadium, zirconium, niobium and tantalum were determined using inductively coupled plasma-mass spectrometry (ICP-MS). ${ }^{37)}$ The isotopic mass numbers used were as follow: Ti:49, Al:27, $\mathrm{V}: 51, \mathrm{Zr}: 90, \mathrm{Nb}: 93$ and Ta:181 so as to minimize the influence of the matrix. Single-element standard solutions (SPEX CertiPrep, Inc., $1000 \mu \mathrm{g} / \mathrm{mL}$ ) were diluted for use as the titanium, aluminum, vanadium, zirconium, niobium and tantalum standard solutions. The working curves were established in concentrations of 5 points and above. Inductively coupled plasma-mass spectrometry measurement was performed in a clean room (class 10000) and the measurement solutions were prepared in a clean bench (class 100). The analytical detection limits for the metal elements under these conditions were all below $0.05 \mathrm{ng} / \mathrm{g}$. The solutions for analysis were stored in Falcon centrifugal containers cleaned with 5 vol\% concentrated $\mathrm{HNO}_{3}$ solution and ultrapure water.

A solution without a metallic specimen was kept under similar conditions and used for the blank test. The quantity of each metal ion $\left(\mu \mathrm{g} / \mathrm{cm}^{2}\right)$ released from the titanium alloys was estimated using the following formula: (amount of solution: $50 \mathrm{~mL}) \times[($ metal concentration in each test solution $)-($ mean metal concentration in blank test with three bottles)]/(surface area of specimen). The average and standard deviation values of the quantities of released metallic ions were calculated for five bottles. 
Table 2 Comparison of quantity $\left(\mu \mathrm{g} / \mathrm{cm}^{2}\right)$ of various metal ions released from Ti alloys.

\begin{tabular}{|c|c|c|c|c|c|c|c|c|c|c|}
\hline \multirow[t]{2}{*}{ Solution } & \multicolumn{3}{|c|}{ Ti-6Al-4V ELI } & \multicolumn{3}{|c|}{$\mathrm{Ti}-6 \mathrm{Al}-7 \mathrm{Nb}$} & \multicolumn{4}{|c|}{$\mathrm{Ti}-15 \mathrm{Zr}-4 \mathrm{Nb}-4 \mathrm{Ta}$} \\
\hline & $\mathrm{Ti}$ & $\mathrm{Al}$ & V & $\mathrm{Ti}$ & $\mathrm{Al}$ & $\mathrm{Nb}$ & $\mathrm{Ti}$ & $\mathrm{Zr}$ & $\mathrm{Nb}$ & $\mathrm{Ta}$ \\
\hline PBS(-) & - & - & - & - & - & - & 一 & - & - & - \\
\hline$\alpha$-Medium & - & - & - & - & - & - & - & - & - & - \\
\hline Fetal bovine serum & $\begin{array}{c}0.02 \\
\pm 0.007\end{array}$ & 一 & - & $\begin{array}{c}0.02 \\
\pm 0.004\end{array}$ & 一 & $\begin{array}{c}0.0003 \\
\pm 0.0001\end{array}$ & $\begin{array}{c}0.006 \\
\pm 0.001\end{array}$ & - & - & - \\
\hline $\begin{array}{c}0.05 \text { mass } \% \\
\mathrm{HCl}\end{array}$ & $\begin{array}{c}1.59 \\
\pm 0.01\end{array}$ & $\begin{array}{c}0.12 \\
\pm 0.02\end{array}$ & $\begin{array}{c}0.06 \\
\pm 0.001\end{array}$ & $\begin{array}{c}1.12 \\
\pm 0.02\end{array}$ & $\begin{array}{c}0.09 \\
\pm 0.002\end{array}$ & $\begin{array}{c}0.018 \\
\pm 0.001\end{array}$ & $\begin{array}{c}0.38 \\
\pm 0.03\end{array}$ & & $\begin{array}{c}0.02 \\
\pm 0.001\end{array}$ & 一 \\
\hline $\begin{array}{c}1 \text { mass } \% \\
\text { Lactic acid }\end{array}$ & $\begin{array}{c}1.77 \\
\pm 0.05\end{array}$ & $\begin{array}{c}0.12 \\
\pm 0.02\end{array}$ & $\begin{array}{c}0.06 \\
\pm 0.002\end{array}$ & $\begin{array}{c}1.77 \\
\pm 0.05\end{array}$ & $\begin{array}{c}0.14 \\
\pm 0.01\end{array}$ & $\begin{array}{c}0.13 \\
\pm 0.005\end{array}$ & $\begin{array}{c}0.54 \\
\pm 0.01\end{array}$ & $\begin{array}{l}0.044 \\
\pm 0.01\end{array}$ & $\begin{array}{c}0.019 \\
\pm 0.001\end{array}$ & $\begin{array}{c}0.011 \\
\pm 0.001\end{array}$ \\
\hline
\end{tabular}

-: Not Detected

\section{Results and Discussion}

\subsection{Metal release}

The quantities of each metal ion $\left(\mu \mathrm{g} / \mathrm{cm}^{2}\right)$ released from the Ti-6Al-4V, vanadium-free $\mathrm{Ti}-6 \mathrm{Al}-7 \mathrm{Nb}$ and $\mathrm{Ti}-15 \mathrm{Zr}-4 \mathrm{Nb}-$ 4Ta alloys were obtained by immersion test in pseudo body fluids, and are summarized in Table 2. It was observed that the quantities of the titanium ion and each element released from these three titanium alloys changed depending on the element added to the titanium alloy and the composition of the immersion test solution. The quantities of the titanium ions released into the PBS(-), $\alpha$-medium and fetal bovine serum were very small and much lower than those released into the 1.2 mass $\%$ L-cysteine, 0.05 mass $\% \mathrm{HCl}$ and 1 mass \% lactic acid solutions with lower $\mathrm{pH}$ levels than the medium solution. The quantity of the metal ions released from the titanium alloy became considerably larger in the 1.2 mass\% L-cysteine solution with an amino acid. In particular, the quantities of metal ions released into the 1 mass\% lactic acid solution followed by the $0.05 \% \mathrm{HCl}$ solution were the highest in the 1.2 mass \% Lcysteine, 0.05 mass $\% \mathrm{HCl}$ and 1 mass $\%$ lactic acid solutions. The quantity of titanium ions released from the polished $\mathrm{Ti}-6 \mathrm{Al}-4 \mathrm{~V}$ alloy into bovine serum at $37^{\circ} \mathrm{C}$ was approximately $0.02 \mu \mathrm{g} / \mathrm{cm}^{2}{ }^{21)}$ The quantity of titanium ions released from the Ti-6Al-4V alloy into $0.17 \mathrm{~mol} / \mathrm{L} \mathrm{NaCl}$ containing $0.0027 \mathrm{~mol} / \mathrm{L}$ EDTA was approximately $1.0 \mu \mathrm{g} / \mathrm{cm}^{2}{ }^{20)}$ These results are in close agreement with those obtained in the immersion test. It was suggested that the 1 mass\% lactic acid solution was promising as an acceleration solution for immersion testing.

The quantity of titanium ions released from the $\mathrm{Ti}-15 \mathrm{Zr}-$ $4 \mathrm{Nb}-4 \mathrm{Ta}$ alloy was much smaller than that released from the Ti-6Al-4V alloy. The quantity of each element released from the three titanium alloys is compared with that of titanium ions released in Figs. 5 to 7 . In the 1.2 mass\% L-cysteine, 0.05 mass $\% \mathrm{HCl}$ and 1 mass $\%$ lactic acid solutions, vanadium and aluminum ions were released from the Ti-6Al-4V alloy (Fig. 5). In the case of the Ti-6Al-7Nb alloy, the quantity of niobium ions released into the 1.2 mass \% L-cysteine or 0.05 mass $\% \mathrm{HCl}$ solution was smaller than that released into the 1 mass\% lactic acid solution (Fig. 6). For the Ti-15Zr$4 \mathrm{Nb}-4 \mathrm{Ta}$ alloy, the quantity of zirconium ions released into

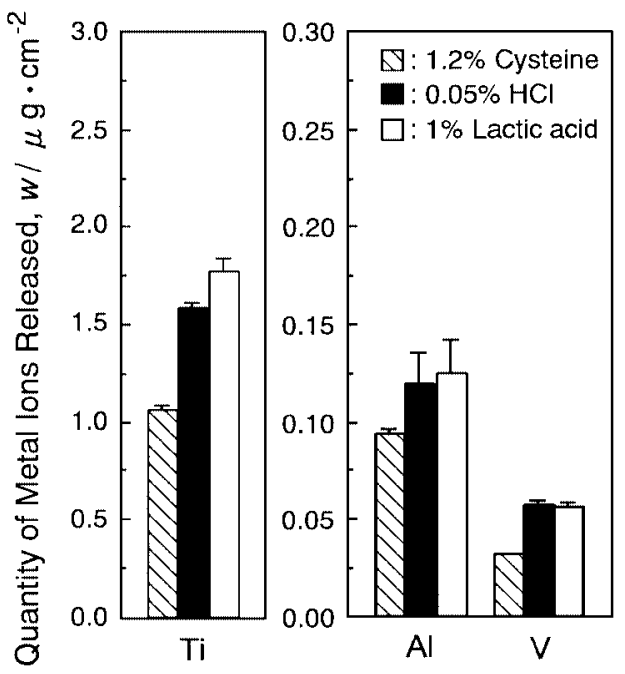

Fig. 5 Quantities of metal ions released from Ti-6Al-4V ELI alloy into 1.2 mass $\%$ cysteine, $0.05 \%$ mass $\% \mathrm{HCl}$ and 1 mass $\%$ lactic acid solutions at $37^{\circ} \mathrm{C}$ after one week.

the 1.2 mass \% L-cysteine or 0.05 mass $\% \mathrm{HCl}$ solution was much smaller than that released into the 1 mass $\%$ lactic acid solution (Fig. 7). A small amount of niobium ions was released into the 0.05 mass $\% \mathrm{HCl}$ or 1 mass $\%$ lactic acid solution. Moreover, only a small amount of tantalum ions was released into the 1 mass $\%$ lactic acid solution.

The ratio of the quantity of titanium ions released from the $\mathrm{Ti}-15 \mathrm{Zr}-4 \mathrm{Nb}-4 \mathrm{Ta}$ or $\mathrm{Ti}-6 \mathrm{Al}-7 \mathrm{Nb}$ alloy to that released from the Ti-6Al-4V alloy (1.0 for control) is shown in Fig. 8. In fetal bovine serum and 1 mass $\%$ lactic acid solutions, the quantities of titanium ion released from Ti-6Al-4V and Ti-6Al$7 \mathrm{Nb}$ alloys were almost equal. In the 1.2 mass $\%$ L-cysteine and 0.05 mass $\% \mathrm{HCl}$ solutions, the quantity of titanium ions released from the Ti-6Al-7Nb alloy was approximately $75 \%$ of that of titanium ions released from the Ti-6Al-4V alloy. The quantities of titanium ions released from the Ti-15Zr$4 \mathrm{Nb}-4 \mathrm{Ta}$ alloy into the fetal bovine serum, 1.2 mass $\% \mathrm{~L}-$ cysteine, 0.05 mass $\% \mathrm{HCl}$ and 1 mass $\%$ lactic acid solutions were considerably smaller, being approximately $30 \%$ of that of the titanium ions released from the Ti-6Al-4V alloy.

The ratio of the total quantity of each element other than titanium released from the $\mathrm{Ti}-15 \mathrm{Zr}-4 \mathrm{Nb}-4 \mathrm{Ta}$ and $\mathrm{Ti}-6 \mathrm{Al}-$ 

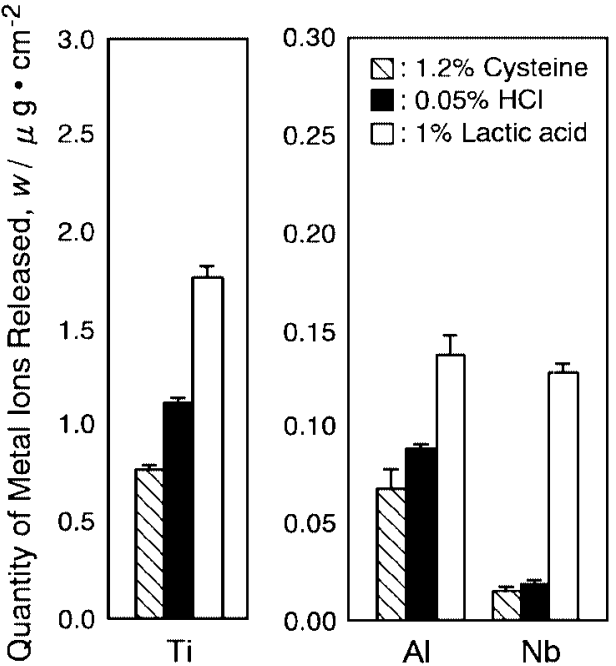

Fig. 6 Quantities of metal ions released from $\mathrm{Ti}-6 \mathrm{Al}-7 \mathrm{Nb}$ alloy into $1.2 \%$ mass $\%$ cysteine, $0.05 \%$ mass $\% \mathrm{HCl}$ and 1 mass $\%$ lactic acid solutions at $37^{\circ} \mathrm{C}$ after one week.
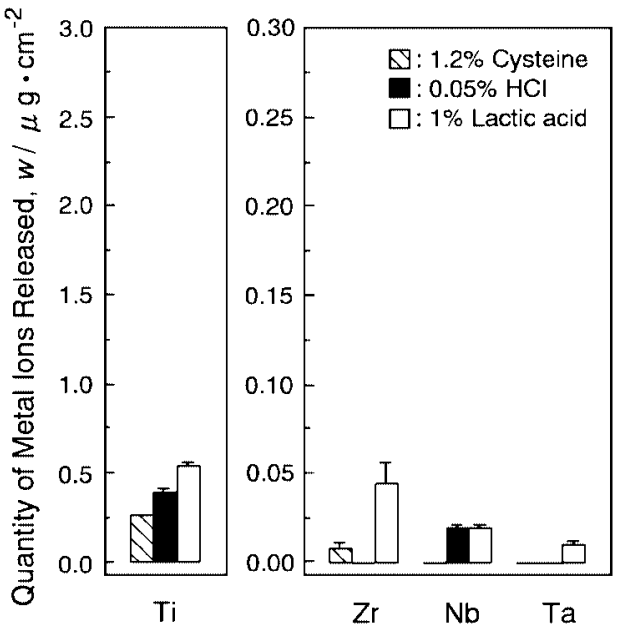

Fig. 7 Quantities of metal ions released from $\mathrm{Ti}-15 \mathrm{Zr}-4 \mathrm{Nb}-4 \mathrm{Ta}$ alloy into $1.2 \%$ mass $\%$ cysteine, $0.05 \%$ mass $\% \mathrm{HCl}$ and 1 mass \% lactic acid solutions at $37^{\circ} \mathrm{C}$ after one week

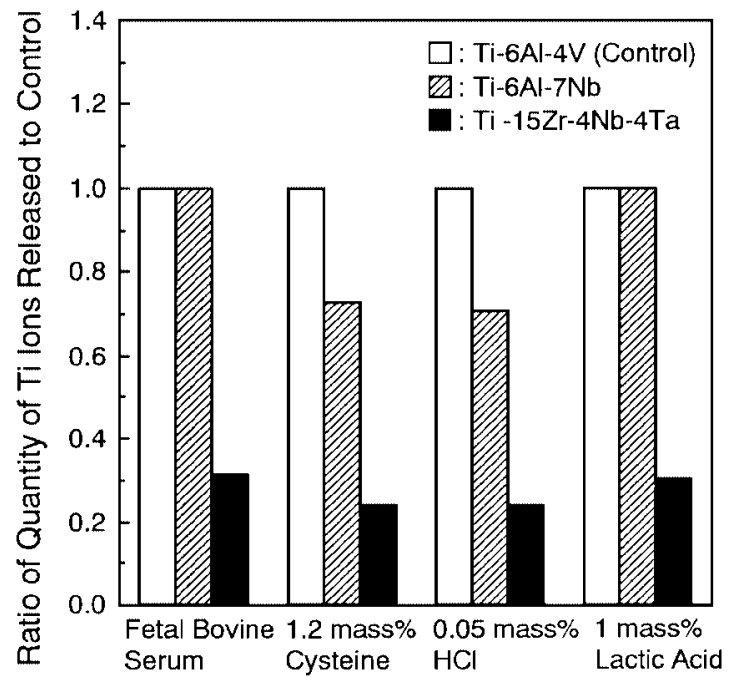

Fig. 8 Comparison of the ratios of quantity for $\mathrm{Ti}$ ions released from Ti-6Al-7Nb and Ti-15Zr-4Nb-4Ta alloys to that of Ti ions released from Ti-6Al-4V alloy as control (1.0).

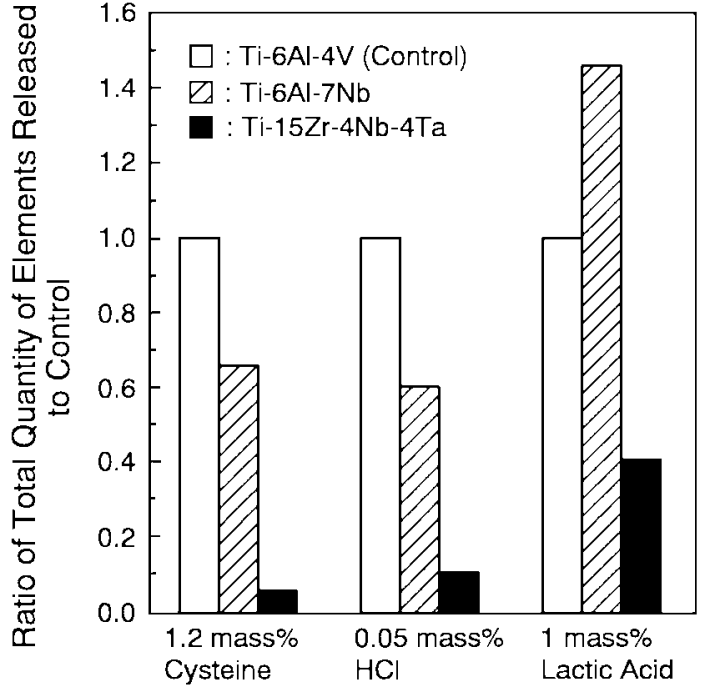

Fig. 9 Comparison of the ratios of total quantity of each element released from $\mathrm{Ti}-6 \mathrm{Al}-7 \mathrm{Nb}$ and $\mathrm{Ti}-15 \mathrm{Zr}-4 \mathrm{Nb}-4 \mathrm{Ta}$ alloys to the total quantity of $\mathrm{Al}$ and $\mathrm{V}$ ions released from Ti-6Al-4V alloy for control (1.0).

$7 \mathrm{Nb}$ alloys to that of aluminum and vanadium ions released from the Ti-6Al-4V alloy (1.0 for control) is shown in Fig. 9. In the 1 mass $\%$ lactic acid solution, the total quantity of aluminum and niobium ions released from the Ti-6Al-7Nb alloy was larger than that of aluminum and vanadium ions released from the Ti-6Al-4V alloy. It is clear that the total quantities of the elements released from the $\mathrm{Ti}-15 \mathrm{Zr}-4 \mathrm{Nb}-4 \mathrm{Ta}$ alloy were much smaller than those of the elements released from the Ti-6Al-4V or Ti-6Al-7Nb alloy.

\subsection{Experimental fabrication of implants}

Bone plates, artificial hip joints of the cementless type and artificial tooth implants were successfully fabricated with the Ti-15Zr-4Nb-4Ta alloy (Fig. 10). The surface of the bone plate was modified by anodic oxidation. Part of the neck on the stem surface of the artificial hip joint shown in Fig. 10(b) was experimentally fabricated by the same surface treatment used for advanced cementless artificial hip joints made of the Ti-6Al-2Nb-1Ta alloy. ${ }^{39,40)}$

\section{Conclusions}

The release of metal ions from the Ti-15Zr-4Nb-4Ta alloy in pseudo body fluids was compared with that from the Ti-6Al-7Nb and Ti-6Al-4V alloys in order to choose an optimum acceleration solution for immersion testing. Bone plates, artificial hip joints of the cementless type and artificial tooth implants were experimentally fabricated using the Ti$15 \mathrm{Zr}-4 \mathrm{Nb}-4 \mathrm{Ta}$ alloy. The following conclusions were drawn.

The quantities of titanium ions released into the PBS(-), $\alpha-$ medium and fetal bovine serum were much smaller than those released into the 1.2 mass $\% \mathrm{~L}$-cysteine, $0.05 \mathrm{mass} \% \mathrm{HCl}$ and 1 mass $\%$ lactic acid solutions. It was suggested that 1 mass $\%$ lactic acid solution was promising as an acceleration solution for immersion testing. The quantity of the titanium ions released from the $\mathrm{Ti}-6 \mathrm{Al}-7 \mathrm{Nb}$ alloy was approximately $75 \%$ of that of the titanium ions released from the Ti-6Al-4V alloy in 1.2 mass \% L-cysteine and 0.05 mass $\% \mathrm{HCl}$ solutions. Other- 
(a)

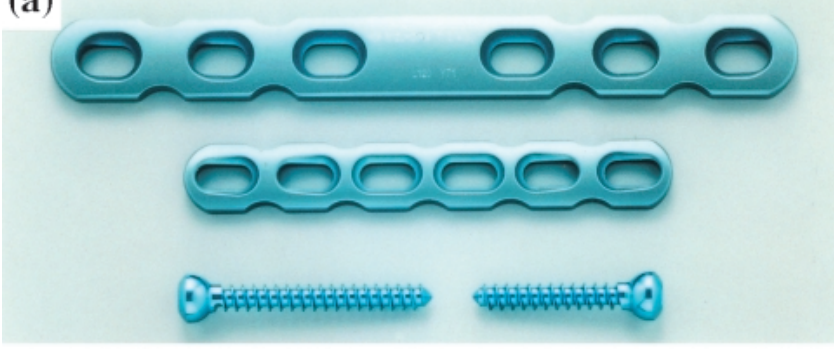

(b)

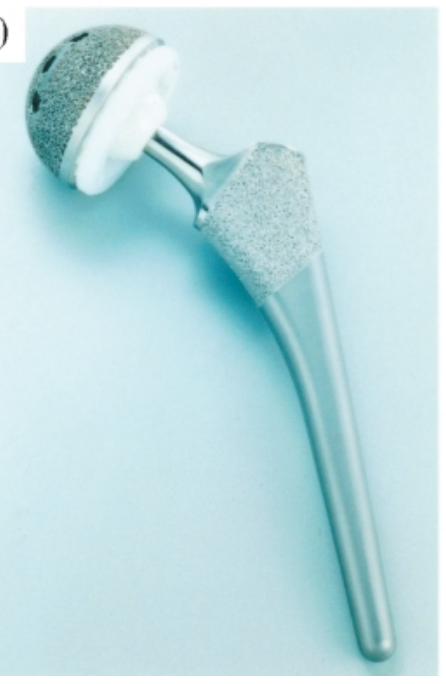

(c)

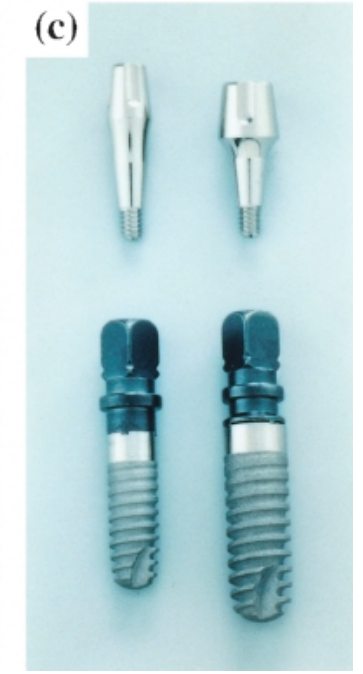

Fig. 10 Bone plate (a), cementless artificial hip joint (b) and artificial tooth implant (c) made of $\mathrm{Ti}-15 \mathrm{Zr}-4 \mathrm{Nb}-4 \mathrm{Ta}$ alloy.

wise, the quantities of the titanium ions released from the Ti$15 \mathrm{Zr}-4 \mathrm{Nb}-4 \mathrm{Ta}$ alloy into the fetal bovine serum, 1.2 mass $\%$ L-cysteine, 0.05 mass $\% \mathrm{HCl}$ and 1 mass\% lactic acid solutions were considerably smaller, being approximately $30 \%$ of the quantity of the titanium ions released from the Ti$6 \mathrm{Al}-4 \mathrm{~V}$ alloy. The quantities of zirconium ions released into the 1.2 mass $\%$ L-cysteine and 0.05 mass $\% \mathrm{HCl}$ solutions were much smaller than that released into the 1 mass\% lactic acid solution. The total quantity of zirconium, niobium and tantalum released from the $\mathrm{Ti}-15 \mathrm{Zr}-4 \mathrm{Nb}-4 \mathrm{Ta}$ alloy was much smaller than that of the elements released from the Ti-6Al$4 \mathrm{~V}$ or Ti-6Al-7Nb alloy. Bone plates, artificial hip joints and artificial tooth implants were successfully fabricated with the Ti-15Zr-4Nb-4Ta alloy using conventional manufacturing processes. The new $\mathrm{Ti}-15 \mathrm{Zr}-4 \mathrm{Nb}-4 \mathrm{Ta}$ alloy with its excellent corrosion resistance is expected to become the preferential titanium alloy for medical applications in the future.

\section{REFERENCES}

1) K. L. Wapner: Clinical Orthop. and Related Res. 271 (1991) 12-20.

2) H. J. Agins, N. W. Alcock, M. Bansal, E. A. Salvati, P. D. Wilson, Jr., P. M. Pellicci and P. G. Bullough: J. Bone and Joint Surg. 70-A (1988) 347-356.

3) J. J. Jacobs, A. K. Skipor, J. Black, R. M. Urban and J. O. Galante: J. Bone and Joint Surg. 73-A (1991) 1475-1486.

4) J. J. Jacobs, C. Silverton, N. J. Hallab, A. K. Skipor, L. Patterson, J. Black and J. O. Galante: Clinical Orthop. and Related Res. 358 (1999) 173-180.

5) J. Black: Biomaterials 5 (1984) 11-18.
6) C. Johansson, J. Lausmaa, M. Ask, H. A. Hansson and T. Albrektsson: J. Biomed. Eng. 11 (1989) 3-8.

7) D. R. Haynes, S. D. Rogers, S. Hay, M. J. Pearcy and D. W. Howie: J. Bone and Joint Surg. 75-A (1993) 825-834.

8) H. Schliephake, G. Reiss, R. Urban, F. W. Neukam and S. Guckel: Inter. J. Oral \& Maxillofacial Implants 8 (1993) 502-511.

9) P. D. Bianco, P. Ducheyne and J. M. Cuckler: J. Biomed. Mater. Res. 31 (1996) 227-234.

10) A. B. Ferguson, Jr., P. G. Laing and E. S. Hodge: J. Bone and Joint Surg. 42-A (1960) 77-90.

11) L.-E. Moberg, A. Nordenram and O. Kjellman: Int. J. Oral Maxillofac. Surg. 18 (1989) 311-314.

12) S. J. Lugowski, D. C. Smith, A. D. McHugh and J. C. Van Loon: J. Biomed. Mater. Res. 25 (1991) 1443-1458.

13) J. L. Woodman, J. J. Jacobs, J. O. Galante and R. M. Urban: J. Orthop. Res. 1 (1984) 421-430.

14) A. B. Ferguson Jr., Y. Akahoshi, P. G. Laing and E. S. Hodge: J. Bone and Joint Surg. 44-A (1962) 317-322.

15) A. B. Ferguson Jr., Y. Akahoshi, P. G. Laing and E. S. Hodge: J. Bone and Joint Surg. 44-A (1962) 323-336.

16) A. Wisbey, P. J. Gregson, L. M. Peter and M. Tuke: Biomaterials 12 (1991) 470-473.

17) M. Browne and P. J. Gregson: Biomaterials 15 (1994) 894-898.

18) R. Strietzel, A. Hosch, H. Kalbfleisch and D. Buch: Biomaterials 19 (1998) 1495-1499.

19) K. E. Healy and P. Ducheyne: J. Biomed. Mater. Res. 26 (1992) 319338.

20) K. E. Healy and P. Ducheyne: Medical Applications of Titanium and Its Alloys: The Material and Biological Issues, ASTM STP 1272, eds. S. A. Brown and J. E. Lemons (ASTM, U.S.A., 1996) pp. 179-187.

21) P. Kovacs and J. A. Davidson: Medical Applications of Titanium and Its Alloys: The Material and Biological Issues, ASTM STP 1272, eds. S. A. Brown and J. E. Lemons (ASTM, U.S.A., 1996) pp. 163-175.

22) S. G. Steinemann: Evaluation of Biomaterials, eds. G. D. Winter, J. L. Leray and K. de Goot (Wiley, Chichester, 1980) pp. 1-34.

23) S. G. Steinemann: Materials for Medical Engineering, eds. H. Stallforth and P. Revell, Euromat 99, Volume 2, (Wiley-VCH, 1999) pp. 199-203.

24) Y. Okazaki, S. Rao, S. Asao, T. Tateishi, S. Katsuda and Y. Furuki: Mater. Trans., JIM 39 (1998) 1053-1062.

25) Y. Okazaki, S. Katsuda, Y. Furuki and T. Tateishi: Mater. Trans., JIM 39 (1998) 1063-1069.

26) Y. Okazaki, S. Rao, S. Asao and T. Tateishi: Mater. Trans., JIM 39 (1998) 1070-1079.

27) Y. Okazaki, Y. Ito, A. Ito and T. Tateishi: Mater. Trans., JIM 34 (1993) 1217-1222.

28) Y. Okazaki, A. Ito, T. Tateishi and Y. Ito: Mater. Trans., JIM 35 (1994) 58-66.

29) A. Ito, Y. Okazaki, T. Tateishi and Y. Ito: J. Bio Mater. Res. 29 (1995) 893-900.

30) Y. Okazaki, Y. Ito, A. Ito and T. Tateishi: Medical Applications of Titanium and Its Alloys: The Material and Biological Issues, ASTM STP 1272, eds. S. A. Brown, J. E. Lemons (ASTM, U.S.A., 1996) pp. 45-59.

31) Y. Okazaki, Y. Ito and T. Tateishi: Mater. Trans., JIM 37 (1996) 138147.

32) Y. Okazaki, Y. Ito, K. Kyo and T. Tateishi: Mater. Sci. Eng. A 243 (1998) 250-256.

33) Y. Okazaki, T. Tateishi and Y. Ito: Mater. Trans., JIM 38 (1997) 78-84.

34) Y. Okazaki, K. Kyo, Y. Ito and T. Tateishi: Mater Trans., JIM 38 (1997) 344-352.

35) Y. Okazaki, S. Rao, T. Tateishi and Y. Ito: Mater. Sci. Eng. A 243 (1998) 250-256.

36) Y. Okazaki, S. Rao, Y. Ito and T. Tateishi: Biomaterials 19 (1998) $1197-$ 1215.

37) Y. Okazaki and E. Nishimura: Mater. Trans., JIM 41 (2000) 1247-1255.

38) Y. Okazaki: Biomaterials 23 (2002) 2071-2077.

39) K. Ido, Y. Matsuda, T. Yamamuro, H. Okumura, M. Oka and H. Takagi: Acta Orthop. Scand. 64 (1993) 607-612.

40) T. Yamamuro, T. Nakamura, H. Iida and Y. Matsuda: Joint Arthroplasty, eds. S. Imura, M. Wada and H. Omori (Springer, Tokyo, 1999) pp. 213224. 